\title{
The Afterlives of Those Who Write Themselves: Rethinking Autobiographical Archives
}

\author{
Sidonie Smith \\ University of Michigan \\ Julia Watson \\ The Ohio State University
}

\begin{abstract}
As those who write themselves, life narrators are readers, interpreters, and curators of the archival material, both intimate and impersonal, accrued during their lifetimes. These materials form an archival pre-life that is extended and complemented by posthumous remediations of their narrated lives. Personal archives may include writing in journals and diaries, digital exchanges on social media and blogs, documents, and images in photographs and drawings, as well as the ephemera of recorded memories and impressions; as this archive is activated in life writing, its texts project an archival imaginary. Once a life narrative enters public circulation, the archive of self accrues future 'afterlives' as it is edited, reframed, and remediated in subsequent editions and by translation into other languages or media for different reading publics, both during and after a writer's life.

The interactive relationship of self-archives and afterlives makes clear that the texts of self-life-writing, whether published or unpublished, complete or fragmentary, are objects of inquiry in movement - not transparent, stable phenomena that generate 'truth,' but dynamic sites open to interpretation in their textual afterlives. An autobiographical narrative is, thus, never just 'the life': supplements, remediations, and new versions are created in interactions with the practices and positions of new generations of readers. This essay takes up the iterative, interactive, and intersubjective dynamics of autobiographical archives and the temporalities of autobiographical afterlives in eight exemplary cases of life writing. Observing autobiographical archives in their histories of
\end{abstract}


circulation, republication, and repurposing situates the question of afterlives as a mode of 'beyond endings' in larger debates about ethical reading, methodological constraint, and theoretical adequacy.

Keywords: textual afterlives, archives of feelings and impressions, remediation and/as afterlife, digital afterlives

[T] he question of the archive is not [. . ] a question of the past. . . It is a question of the future, the question of the future itself, the question of a response, of a promise and of a responsibility for tomorrow.

Jacques Derrida, Archive Fever

\section{INTRODUCTION}

As our epigraph from Derrida suggests, engaging the archives of texts directs readers away from their pastness and toward the continuing futurity of their afterlives. While formal and institutional archives abound and inform much historical and biographical scholarship, all of us are, in a sense, archives unto ourselves, storing the remembered experiences of past life in memories, emotions, artifacts, documents, and memorabilia. Admittedly, accumulating autobiographical material over a lifetime is not, in and of itself, an autobiographical act; but it contributes to creating a personal archive out of which autobiographical acts and practices evolve. These ongoing archival accretions may be stored, revised, and curated repeatedly as moments of self-survey and self-reflection increase and shift. In an age when social media and self-curation generate numerous user documents, this point may seem obvious; but it is not particular to the contemporary moment.

That is, in our view, those who write themselves may also be seen as the readers, interpreters, and curators of their accreted archival material, material that ranges from the intimacy of earlier self-writing in journals, letters, and diaries, self-imaging in photographs and drawings, family and community memorabilia, favorite or go-to books, songs, and sayings, attachments and feelings, and dispositions of the body, to transpersonal historical documents, narratives, and films. Archives are stored not only in boxes, on bookshelves, on social media platforms, and in the cloud, but in the synapses of memory, as our bodies store a reservoir of memories and felt experience from which autobiographical acts can be drawn. 
Narrators may interpret this 'pre-life' archive of their pasts and access earlier versions of self-inscription in crafting, resituating, and positioning themselves as subjects.

Canadian archivists Jennifer Douglas and Heather MacNeil, drawing on our analysis in Reading Autobiography (2001) and Sidonie's essay on performativity, observe that 'when read as a personal and psychological text, a writer's archive is deeply ambiguous; the writer herself is continually performing different versions of the self, and various other selves - friends, colleagues, and archivists among others - participate in shaping the meaning of the archive.' They go on to argue that 'a writer's archive is perhaps best understood as a social and collaborative text rather than a purely psychological one.' ${ }^{1}$ While we appreciate the complexities of Douglas and MacNeil's three-fold attention to the 'ongoing conversation between the writer and her various selves,' the archivist's arrangements of curatorial material, and the user/reader's co-interpretations of the subject's life, our attention is directed to other issues: the archival imaginary of autobiographical texts; the iterative, interactive, intersubjective dynamics of autobiographical archives; and the temporalities of autobiographical afterlives. In one sense, of course, life writing texts are already 'afterlives' they emerge after the living and initial interpreting of personal experience. But the concept of afterlives encompasses multiple effects, such as the resurfacing of autobiographical material in later writing; the citation of earlier models of life writing within personal narratives; the perspectives of editors and readers generated with the circulation and reception of various editions; and the incomplete and unstable nature of archives themselves that, as Derrida suggests, gesture toward futurity. ${ }^{2}$

Thus the relationship of archives to afterlives extends beyond written, drawn, and performed texts. A written life entering the world as a book, manuscript, blog, or the like, is filtered through other kinds of archives and may be changed by subsequent editions or translations into different media and languages. That is, a published 'life' enters into circulation as new reading publics access different versions of it over time; and it acquires an 'afterlife' that shifts its relationship to archival material and generates other versions of the subject. A focus on afterlives makes clear that texts of self-life-writing, whether published or unpublished, fulllength or fragmentary, are objects of inquiry in movement - not transparent, stable phenomena that generate 'truth,' but dynamic sites open to interpretation over the course of their textual afterlife. An autobiographical narrative is, thus, never just 'the life': there are supplements, remediations, and new versions interacting with new generations of readers.

In this sense our inquiry is complementary to that of Philippe Lejeune, who has focused on the 'genesis' or pre-life of autobiographical narratives 
and the evidence of that process in photos, documents, and explicit references to events, places, and people within a text before its creation. We understand such materials as implicitly archival and explore the interaction of such archives with their afterlives of self-curation, circulation and/ or publication, and remediation, which may extend well beyond a writer's life, signaling the changeable and dynamic status of life narrative.

Three key concepts inform our exploration of the afterlives of written, drawn, or digital self-presentations and the archival traces they incorporate. 1) Far from being transparent, autobiographical narration involves complex processes of self-curation and -interpretation across multiple, situated vantage points. 2) Every autobiographical ' $I$ ' is really a multitude of 'I's' (including the narrating 'I', narrated 'I', and ideological 'I' but excluding the historical figure), each with different relationships to one another and to the reader. 3) The ' $\mathrm{I}$ ' is not stable, but may shift its referent and speaking position; and it may also be an assemblage of narrators composed as a collective 'we.' Drawing on these concepts, we turn to eight cases of archival afterlives that arise over time in autobiographical texts: troubled authenticity in diary eyewitnessing, afterlives of archived feelings and impressions, afterlives of the inscribed past, postmemorial afterlives situated in world-historical events, transtextuality in anthologized lives, afterlives generated in paratexts and republication, afterlives threatened by new evidence, and aggregated archives in digital media. Our purpose here is not to engage the field of archive studies itself, nor is it to provide a deep dive into one kind of archival afterlife. Rather, we cast our net widely, to encourage colleagues in life writing studies to attend to the heterogeneous ways in which the conjoined concepts of archive and afterlife may signify at this precarious moment and historically. Indeed, untangling and entangling autobiographical archives from and in the histories of circulation, republication, and repurposing of texts situates the question of afterlives in larger debates about ethical reading, methodological constraint, and theoretical adequacy that we hope will resonate with $E J L W$ readers.

AFTERLIVES AND THE TROUBLED 'AUTHENTICITY' OVER TIME OF DIARY EYEWITNESSING

The diary is often considered the most transparent of autobiographical genres, an intimate, unpolished, register of quotidian life as it is lived in an ongoing, unreflective present. For scholars searching archives to find traces of a subject's life, the diary would seem a particularly valuable find, promising an unfiltered glimpse into her or his past. But the archival 
evidence of even a childhood diary invites scrutiny, precisely because the impression of transparency can be deceptive. For instance, diarists often reread their earlier entries and may reinterpret them in the margins, especially in unpublished works. That is, in diaries, as in other forms of life writing, tracking the record of past versions of a self, which comprise the afterlife of the original text, may uncover a dynamic and changing subject.

Consider a seemingly unproblematic example of the published diary as a day-to-day record of events as they happened. For a two-year period from September 1991 to October 1993, Zlata Filipović, a young BosnianCroat girl, kept a diary in which she recorded her family's everyday life as Sarajevo was increasingly under fire during the Bosnian-Serbian war. She described, and sometimes reflected upon, the disruption and gradual disintegration of their middle-class way of life during the months of assault by Bosnian Serb paramilitaries. In summer 1993, Zlata showed her diary to her teacher, who found a publisher for it in Croatian by UNICEF, through the sponsorship of the International Centre for Peace. As it gained recognition in Bosnia for its original view of the siege through the eyes of a young girl, Zlata became a 'celebrity' victim, and was heralded as 'the young Anne Frank' of Sarajevo. International journalists covering the war began to reference Zlata's Diary. A French photographer took a copy of it to Paris, where Le Robert Laffont-Fixot published it as Journal de Zlata. Subsequently the diary, expanded with further entries over the intervening months, was published by Viking Penguin in the United States (1994). There it reached an ever-widening audience and was incorporated into the social studies curriculum in some public schools.

Zlata's Diary was thus acclaimed as the transcription of a teenager's earnest personal diary, a document of the traumatic vulnerability of her family's everyday life in Sarajevo during a world-historical event of ethnic and nationalist violence. Yet the diary raises complex questions about authenticity and representativeness, because it was modeled specifically on and linked to The Diary of Anne Frank. That is, its affective appeal draws on an earlier teenager's diary that has become an icon of childhood innocence seared into world memory after the genocidal violence of the Holocaust. Within her diary, Zlata is conscious of the importance of her narrative for others; after it was published, she writes about becoming a 'personality' in Sarajevo and recognizes that, as a child of Sarajevo, she represents what journalists and advocates called the tragedy of 'lost childhood.' Paradoxically, the self-conscious performativity of the diary undermines the transparency effect of the innocent child witness and the "child's eye view. ${ }^{3}$ As a pastiche incorporating public response to its initial published version, the international versions and translations of Zlata's Diary indicate how 
eye-witness records are inflected and changed by their interaction with reading publics and media reception. The afterlife of the initial text resonates with - and may incorporate - responses to it in a feedback loop.

Additionally, when Zlata's Diary was published outside Bosnia, later editions added photographs that visualize the young girl's story of 'lost childhood' in ways that reproduced a calculated 'innocence effect.' For example, a photo of Zlata in bed is framed by the caption 'Zlata, who loves books, reads by candlelight.' The flashbulb used to photograph the intimacy of this candlelight scene exposes the artifice of 'innocent childhood.' In sum, while the diary itself was not 'inauthentic' as witness testimony, its commercialization exposed what Lauren Berlant has described as a 'sentimental politics' that obscures the difficult ethnic politics of the war's violence. In this example of a diary's afterlife, thorny issues emerge. When a published autobiographical work enters routes of international circulation and reception that remake it, and its writer, as an artifact for consumption, how are we to frame its versions? Zlata's Diary enters into an 'archival feed-back loop,' because the diary of one child's everyday experience of violence depends upon the records and materials of another girl's Anne Frank's - life-in-hiding. Through this 'likeness' Zlata increasingly understands herself as a public and historical actor, as the diary's circulation generates its 'afterlife.'

\section{AFTERLIVES OF IMPRESSIONS IN SUBJECTIVE TIME}

As our discussion of Zlata's Diary suggests, eyewitness accounts encounter issues in winning the reader's belief and having the documentary 'truth' of the narrative validated. But another kind of eyewitness account, one stressing feelings or impressions, has also been of great significance in life writing. Ann Cvetkovich, in An Archive of Feelings, acknowledges Derrida's argument about the impossibility of archival truth, because all archives are sites 'of contests over knowledge and power. ${ }^{5}$ But she draws on many kinds of evidence, particularly in gay and lesbian archives, of such material as documentary films and everyday 'oral history, personal photographs and letters, and ephemera' to argue for the existence of an archive of feelings, which she defines as 'a practice of fantasy made material' that focuses on emotion and feeling. ${ }^{6}$

In Cvetkovich's terms, published narratives might productively be thought of as "impressions ${ }^{17}$ rather than objective records because they suggest how memory is crafted, even when writers assert their authority as eyewitnesses. Consider this example: In the early twentieth century, Chicago-born Mary Borden, despite being an heiress and the mother 
of three small children, volunteered as a nurse during World War I and worked for four years behind the Belgian and French sectors of the Western front. The Forbidden Zone: A Nurse's Impressions of the First World War is her collection of seventeen brief vignettes dramatizing momentary sensations during her experience as a hospital nurse. ${ }^{8}$ Unlike better-known autobiographical narratives, such as Erich Maria Remarque's All Quiet on the Western Front and Vera Brittain's Testament of Youth, ${ }^{9}$ Borden shaped her account as a series of written impressions of remembered moments during her European service, many written in snatches during her hospital service. Although she tried to publish her sketches in 1917, the text was rejected as too controversial. Borden herself described her manuscript as a non-linear 'collection of fragments' that critics found 'ugly' and repetitive. ${ }^{10}$ But in 1929, as readers became more receptive to uncensored accounts of World War I in the mode of Modernist realism, The Forbidden Zone gained an afterlife when she reworked it for publication. ${ }^{11}$ Because her narrative presents memories as felt impressions, the occasional repetitions in its sketches powerfully render the confusion and absurdity of moments on the front in its stark and surreal perspective on the violence and injury of war.

For example, in 'Bombardment,' within three pages the account moves from the appearance of a speck 'travelling high through the mysterious twilight' as 'a whirling engine ${ }^{\text {'12 }}$ to the town's slow awakening to 'terror and bewilderment' ${ }^{13}$ as, from an aerial view, 'Scars appeared on it like the marks of smallpox' and 'gashes appeared in its streets. ${ }^{.14}$ After the airplane 'laughed' at the town, then disappeared in the sunshine, 'the town was left in convulsions. ${ }^{15}$ In this bird's-eye view of bombing devastation, Borden is not a visible presence. The factual record of bombing casualties, however, is converted into a sensory narrative of how war devastated both the areas attacked and the participating soldiers. Through such brief 'impressions' her unnamed narrator powerfully conveys the destructiveness and perversity of the war. Indeed, Malcolm Brown, a historian at the Imperial War Museum in London, declares Borden's work a masterpiece and a 'remarkable contribution to the literature of that conflict' for its searing, yet compassionate, narration of events from the point of view of a nurse in the field. ${ }^{16}$ Borden's reworking of her hastily written sketches links her personal experience to a world-historical event and creates an afterlife of feelings that enriches - but also undercuts, from the point of view of an eyewitness - the accounts in official archives.

An archive of feelings can also disrupt the progressive narrative logic of some genres of life writing, such as the story of successful migration and assimilation. Mary Antin, who emigrated from a Russian shtetl to the U.S. in the late nineteenth century, published The Promised Land: The 
Autobiography of a Russian Immigrant ${ }^{17}$ in 1912 as a narrative of assimilation attesting to her successful Americanization. She asserts that hers is a representative story, written at a time when virulent anti-immigrant discourses permeated debates about 'alien' outsiders and their threat to the early twentieth-century American nation. Antin casts her story as a conversion narrative and tracks the process and project of becoming a clean and proper American subject in ways that foreground the radical discontinuity between the old world of Eastern Europe and the new world of the United States. The first part of her divided text casts her childhood in a Russian shtetl as backward and constraining in its medieval containment of women. By contrast, the second half is a Bildungsroman in which her education occurs not only in formal classrooms but also informally in a settlement house. Antin's willed act of becoming, as a model pupil, makes her an 'American' cultivating its values of entrepreneurial ambition, Emersonian individuality, and progressive femininity.

And yet, passages in The Promised Land disrupt Antin's story of assimilation by disclosing a residual afterlife of unassimilable feelings and sensations. When the narrator reconstructs her childhood in Polotzk from the other side of her conversion to American subjectivity, she discovers that her childhood self is almost totally lost to her. What she can recover are sensory memories: the smells of food and the olfactory affects of eating, particularly her mother's cheesecake: 'Why, I can dream away a half-hour on the immortal flavor of those thick cheese cakes we used to have on Saturday night. ${ }^{18}$ The memory of cheesecake evokes an extended description of a sensorium of embodied attachment that disrupts the pace of the narrative of Americanization and interrupts her representation of the Jewish Pale as oppressive. In drawing on her personal archive of feelings, Antin shows how an archive of past impressions can unsettle a tidy story of incorporation, exposing contradictions, ambivalences, and paradoxes that can occur in the experience of migration from one nation, culture, and history to another. Although the narrator proudly identifies as an assimilated American woman, her felt loss of the past still moves her, however much she frames that time as degrading. Paradoxically, the sensory memories of what has had to be forgotten for assimilation to 'stick' haunt her story.

While access to memories as archives of feeling in life narratives such as these can undercut the authority of official histories, they are valid subjective 'evidence' of the larger public events in which the narrators participated. Our examples of the interpenetration of felt subjectivity with world-historical formations, such as war and mass migration, suggest how individualized, unhomogenized renditions of the experience of historical change and crisis can acquire credence as troubling afterlives that question the coherence of 'official stories' of successful integration. 


\section{AFTERLIVES OF THE INSCRIBED PAST AND ITS TEMPORAL REINSCRIPTIONS}

The memories of the past that occasionally disrupt Antin's immigration narrative as persistent traces of her earlier, unassimilated life can become thematic in a life writer's narrative. For example, diarists rereading their earlier entries may introduce photographs of themselves, family, and friends as evidence of the felt past that undercut claims in their texts or cause them to reread their personal pasts differently. Such new versions can contribute to potential contradictions in a text's afterlife.

A striking example of autobiographical writing displaying explicit shifts in the writer's self-conception, by incorporating later material, is Mary McCarthy's Memories of a Catholic Girlhood. Although this memoir appears to be a chronological narrative of her girlhood and early adult years drawn from essays published in American monthly magazines over more than a decade, each chapter is framed by a reflection composed when she was assembling the book, that calls earlier memories and stories about herself into question. McCarthy's narrative underscores how her self-conception depends on the moment or point of view from which she is focalizing her past. For example, a chapter narrates her grandmother's strict control of her and her brother as the orphaned children were growing up in a home she ruled as a 'center of power. ${ }^{\text {'19 }}$ Yet, in the later reflection that follows this chapter, McCarthy muses, '[i]n one sense I have been unfair here to my grandmother. I show her, as it were, in retrospect, looking back at her and judging her as an adult. But as a child, I liked my grandmother, I thought her a tremendous figure. Many of her faults - her blood-curdling Catholicism, for example - were not apparent to me as faults. ${ }^{20}$ More generally, McCarthy observes, in another reflection on her earlier story, '[t]here are some semi-fictional touches here . . . I arranged actual events so as to make "a good story" out of them. It is hard to overcome this temptation if you are in the habit of writing fiction.'21 Thus, McCarthy's earlier memories are contextualized by the narrator/ editor in a later moment as subjective 'impressions,' even as their authority was previously asserted elsewhere. In short, the narrating 'I' structures an afterlife dynamic of retrospection recursively into her text.

A more recent instance occurs in Fun Home: A Family Tragicomic, the graphic memoir of contemporary American queer artist Alison Bechdel. Her narrating ' $\mathrm{I}$ ' is an adult artist rereading and reflecting on her past in relation to both the history of her family and that of homosexuality in twentieth-century America. The graphic memoir depicts growing up in rural Pennsylvania in a family that runs a funeral ['fun'] home and is comprised of an artistic and autistic group of individuals who inhabit 
their home like an 'artists' colony.' ${ }^{22}$ Part of Fun Home's story is daughter Alison's discovery of her identity as a graphic artist and a lesbian. She must also confront the death of her father, likely by suicide at age 44 when she was 17 , and his suppressed homosexuality, which links his desire to her own emerging feelings. Beautifully drawn and wittily narrated, Fun Home incorporates numerous sketches of documents from both the family's records and young Alison's writings as an artefactual afterlife that attests to its material quality as not just documented, but embodied, family history.

Notable among Fun Home's archives of self are the adolescent diaries that her parents suggested young Alison keep to remedy her obsessivecompulsive disorder. Although her diary's daily chronicles, reproduced in child-scrawl, fill many pages with names and dates, the girl's emerging self-consciousness soon compels her to write 'I think' after each sentence. Then she begins to compress the marking of each perception into a drawn symbol, the circumflex, which she scrawls repeatedly so that the entries become almost unreadable. The diary's inauthenticity increases when Alison, because of her poor penmanship, is made to dictate 'official' episodes of her daily life to her mother, while excluding major personal events in her young life. For example, the narrated 'I's diary has an entry on swimming, but none on getting her first menstrual period; such personal stories are censored in her formal family. Finally, teenaged Alison abandons keeping a diary, which Bechdel sums up as her young self's recognition of 'the implicit lie of the blank page. ${ }^{23}$ It gestures toward the then-unspeakable homosexual desire, shared with her father, that was formative for her sexuality. Ironically, while young Alison cannot keep a conventional diary, that failure becomes the starting point of her innovative autographic self-presentation. That is, Bechdel critiques the value of the archive of her early diary-writing as authentic evidence of her experiential life and exposes, metacritically, how to read for gaps and overwritten moments, an afterlife figured but not spoken. As readers, we move contrapuntally between the narrated 'I's diary in the comic's dialogue boxes and the adult narrating 'I"s meta-commentary in the boxes above them that reference her view now of what she had actually experienced, thought, and felt. As this practice suggests, omissions - marked as such - may be more revealing than the initial written record in attesting to the 'life' of a life narrator.

In these examples, an older narrator emphasizes how she now reads her younger self differently as a subject in formation who was reluctant or unable to disclose her emerging inner history. Both suggest that archival records be read against the grain and offer advice on how to do so by giving them a textual afterlife in one of more media. 


\section{POSTMEMORIAL AFTERLIVES SITUATED IN THE SHIFTING TIMES OF WORLD-HISTORICAL EVENTS}

Some writers, aware of their precarity as victims in world-historical events, seek to manage issues about the afterlife of archival evidence and publication by documenting their stories of vulnerability with multiple public and personal archives that provide the authority of evidence. But in these instances, too, issues may arise.

An example is Art Spiegelman's graphic memoir, Maus: A Survivor's Tale, which references numerous public and family archives that situate his family story within a collective story located at what he has called the 'fault line where World-History and Personal History collide.' ${ }^{24}$ The authorial persona Art, whom Spiegelman creates, is at once an insistent researcher and an unreliable narrator; but the archival documentation he references is authoritative. Maus incorporates many kinds of formal and informal archival material about its own creation. Foremost is the tape transcript of the father Vladek's individual story as a myth of himself; it is juxtaposed to the son 'Art-the-narrator"s less flattering biography of his father, and 'Art-the-artist's story of how he composed the comic.

Spiegelman incorporates many kinds of documents from family archives. There are vignettes for several family members he never knew who were killed or killed themselves during the Holocaust. Genealogical charts, photographs, drawings, and stories allude to his mother's and father's families over generations in Poland. Using public archives, Spiegelman references chronologies of events for European Jews by including maps, the plan of a gas chamber, and the formula for Zyklon $\mathrm{B}$, the poison gas used in them. Citations from books and newspapers display how widespread the Fascist ideology of Aryan superiority and Jewish racial inferiority was. Decades after the war, when Spiegelman made a visit to Auschwitz, he represents Art's access to its mass of documentation in cartoon drawings that readers can verify elsewhere. ${ }^{25}$ In Maus Spiegelman also interweaves his earlier personal diary, 'Prisoner on the Hell Planet,' as a comic that shows young Art as a self-obsessed teenager haunted by his mother's suicide, a story that can be alluded to but not told. That is, gaps - what is not available in the archives or what is too painful to narrate - also comprise part of the story.

Importantly, the evidence in Maus narrates 'history from below.' Its account of the Holocaust is told from the point of view of victims, with a focus on the invasion of Poland, efforts to hide from the invading Nazis and the collaboration of some Poles, arrests and deportations to the death camps, and accounts of life there. Its graphics display the use of extermination technologies, depict the aftermath of the war as a struggle 
to survive in hiding or in refugee camps, and focus on the challenges of exile (for his family, in Sweden) and immigration to New York. Yet this grim documentation is depicted in appealing comic images, with characters represented as various animals that engage readers who may be resistant to the stories of Holocaust victims.

Throughout Maus, then, Spiegelman situates his persona Art in at least three contrasting ways - as resentful son; 'Raw' comics artist; and resourceful researcher who draws on multiple archives in part because, as a child born after World War II, he lacks direct memories of his family's experiences. Memory theorist Marianne Hirsch has described Spiegelman's use of what she calls 'postmemory' in such relationships to the past. ${ }^{26}$ Hirsch and Leo Spitzer assert, "Postmemory" describes the relationship that the "generation after" bears to the personal, collective, and cultural trauma of those who came before - to experiences they "remember" only by means of the stories, images, and behaviors among which they grew up. But these experiences were transmitted to them so deeply and affectively as to seem to constitute memories in their own right. ${ }^{27}$ As they suggest, postmemory describes a mediated connection to the past 'mediated . . . by imaginative investment, projection, and creation.'

Because Spiegelman's comics are created from the position of postmemory, rather than direct memory, they cannot be a transparent recounting - they are inherently stories situated in the afterlives of others. Even the archival documents he references are redrawn, interpreted, and narrativized. As Spiegelman's practice in Maus suggests, no transparent recounting of archival data about earlier events can occur when a researcher is positioned outside them. He or she must consider how to shape the story, what weight to give to varied and conflicting kinds of evidence, and whether to make the story consistent or to highlight tensions and contradictions that fracture it - but may make it more compelling. Thus, Spiegelman's comics assign a multimedial visual afterlife to the experience of both victims and survivors of the Holocaust by incorporating visual and textual historical documents from both personal and public archives to authenticate his truth claims about three generations' experience at the 'faultline' of world history.

\section{TRANSTEXTUAL AFTERLIVES IN TRANSPOSED FRAMEWORKS OF ANTHOLOGIZED LIVES}

So far, our case studies have focused on how self-representation in autobiographical texts is related to a narrative's archives, archival imaginary, archival politics, and archival registers. We have noted how situating 
narratives in the context of their archives can generate surprising afterlives, both within and beyond the text. What happens when personal life narratives are resituated transpersonally, within a larger archive of stories and testimonies that widens their circulation and scope?

A case in point is the afterlife of women's life stories in anthologies. In the West there is a long history of anthologized lives, from the medieval collections of women saints' lives to the nineteenth-century collections of biographies by women sharing a profession or some kind of notoriety; these constitute what literary scholar Alison Booth terms prosopography. ${ }^{28}$ With the advent of second-wave feminism in the later twentieth century, anthologies began to gather women's life narratives into collections that joined the personal and the political, foregrounding the authority of experience. Anthologies focused on such themes as incest and abuse, lesbian coming-out stories, testimonies by women of color attesting to oppression, and the process of decolonization in developing nations. By the end of the century, as discourses of human rights emerged and institutional venues for hearing claims about women's human rights were established, numerous anthologies of women witnessing to radical injury and harm had become available as volumes of personal testimony.

These edited volumes, designed to advance claims for recognition, reparation, and repair, served as published archives that exposed issues about the afterlives of women's witnessing. As Kay Schaffer and Sidonie Smith observe in Human Rights and Narrated Lives: The Ethics of Recognition, when women's stories are published in a collection, either during or after their lifetimes, the editing process situates them in new contexts that affect both how their texts are read and what larger story a collection is made to tell. Indeed, gathering stories into an anthology confers a collective afterlife on individual narratives. Often, the stories are linked as testimonies to experiencing injury and harm, or set in a national or transnational context of violence and suffering. Certainly, human rights campaigns benefit by publishing anthologies that assemble an archive of testimony to shared experiences of victimization, particularly when those are contextualized by scholar-activists who provide historical and contextual information. The aim of such collections, in print and on websites, is to rewrite history, name perpetrators, claim recognition, and inspire further action. Yet, in the arena of rights violations, when an individual's story is resituated in someone else's framework, it may be constrained by discourses to render it intelligible to the intended audience, reinterpreted by the other stories to which it is juxtaposed, and truncated to fit story requirements for a direct, affectively compelling appeal.

For example, in 1994, Danish psychologist Inger Agger collected client narratives in The Blue Room. Trauma and Testimony among Refugee Women: 
A Psychosocial Exploration, framing these women's stories of witness to torture, sexual predation, and imprisonment through a disciplinary lens of traumatic recovery. The room in which she situates the women is at once a space and a trope. Literally, Agger interviewed the women whose stories she gathered in the blue room of her home; figuratively, the 'blue room' references a place of healing. Like the classical memory theater that images the project of remembering as moving through the rooms of a building, the different chapters gather the witness testimony in 'rooms' designated as different kinds of traumatic experience. Walking through memory and working through trauma become entangled. Thus, while the book includes the first-person witness of women from Latin America and the Middle East who lived in Denmark as refugees, the Western paradigm of a therapeutic model of remembering and recovery individualizes the process of recovery at the same time that it simplifies and universalizes the way to recovery.

Such collected volumes of witnessing by women survivors of radical injury and harm have created a massive archive of women's witnessing that is circulated through the global traffic in human rights narratives. Certainly, this work assembles remarkable projects of storytelling from below, stories of women who have been degraded, oppressed, marginalized, abused, dehumanized, and forgotten. But while it is an archival record of significance, it also reveals the effects of the global politics of human rights discourse, institutions, protocols, and methods of circulation on women's stories, as they are caught up in the constraints of human rights claims-making and the disciplinary ideologies of repair and recovery. The anthologized afterlife of their stories is shaped to serve purposes of commodification that they may not have anticipated: the quest of publishers for salable stories of victimization and survival, the investment of perpetrators in denial and defamation, and the pressure to make stories conform to generic templates attuned to the legal parameters of the rights regime.

\section{AFTERLIVES GENERATED BELATEDLY IN PARATEXTS AND REPUBLICATION}

What Gérard Genette calls the paratextual material of a published life story includes all that surrounds it - its framing documents and the publication materials that contribute to its afterlife in multiple editions and versions. ${ }^{29}$ Collectively these comprise an archive of curation and reception that is not a static repository but a multi-sited and changing set of iterations. That is, a narrated life is not just situated in the past of the subject; it is potentially an archive that moves with the present moment and 
aggregates new parts in an afterlife open to change. Our next example explores how significantly a historical text may shift over the decades of its publication and reception.

The captivity narrative of Mary Rowlandson, originally published in 1682 as A True History of the Captivity and Restoration of Mrs. Mary Rowlandson, has a long history of editions spanning over three hundred years. Comparing several editions of a text, such as Rowlandson's, reveals microand macro-level changes in the epitext of the first edition. We can observe when illustrations are included or deleted, note shifts in who authors the preface and afterword, consider when and why appendices are included. Alterations between the first and successive editions also involve changes in book size, typeface, design, quality of paper, cover page, exact title, and so on. As successive editions are issued by different publishers, they may be associated with different communities or groups, even though the original manuscript of Rowlandson was issued by her Puritan community and was authorized by preacher Cotton Mather. Later editions by publishers serving other kinds of community have situated Rowlandson's narrative differently, as do versions by academic publishers preparing the text for scholarly use. That is, various versions of a life narrative are put to different social and cultural uses during a text's print life and, in their afterlives, may address different audiences.

Other life narratives have similarly complex afterlives, for example, the formerly enslaved American Harriet Jacob's narrative of her life before her freedom was purchased, and English medieval writer Margery Kempe's account of her early wanderings on the European continent after she converted to a pious Catholicism. Consequently, researchers must carefully contextualize which version of a print text they are referencing because, often, no 'authoritative version' exists. As life narratives mutate in republication and translation, we might keep several questions about their afterlives in mind: For published work, who made up the reading public or consumers of the life narrative at the time it was written? Who does, subsequently? What roles did groups such as friendship circles, book clubs, libraries, or - now - talk shows and blogs play in the circulation of the narrative? How was the story taken up in the journals, letters, and other memorabilia of readers? Teasing out archival evidence that addresses these issues can yield fascinating information about how cultural reinterpretations of a life narrative have shaped its afterlife.

\section{AFTERLIVES DESTABILIZED BY NEW EVIDENCE}

As we have seen, autobiographical narratives are sites of ongoing renewal and revitalization, as new information provokes critics to alternative 
interpretations that generate different versions of a subject. But evidence can never speak for itself. Consider the work of the Modernist artist-life writer Charlotte Salomon. Her vast painted-and-lettered project, Life? or Theatre? (Leben? oder Theater?), increasingly known among art historians and scholars of the Holocaust, situates the story of her German-Jewish family circle in Berlin, during the rise of the Nazi regime. Salomon escaped persecution for a while by moving, in 1938 at 21, to the south of France, where she furiously painted and wrote a complex story of her family's life informed by the Nietzschean view of life and death espoused by her stepmother-opera singer's voice coach, who was also her secret lover. Unfortunately, when Salomon and her new husband filed their marriage license in the courthouse of Nice during the Vichy regime, the Gestapo rapidly located them. They were arrested in September 1943, and the pregnant Charlotte and her new husband were deported to AuschwitzBirkenau where, at age 26, she was soon murdered. Remarkably, Salomon had given her over 1,300 painted pages to a village doctor who preserved them and in 1947 returned them to her parents, who had survived the war in the Netherlands.

Life? or Theatre?, conceived as a play or 'Singespiel,' an operetta-like work in 784 pages painted and lettered in gouache (plus transparencies and suggested music), narrates the family's troubled past, with eight suicides, most by women, including those of her mother, aunt, and grandmother. Beginning in 1961 Salomon's work was exhibited, eventually worldwide, and given to the Jewish Historical Museum in Amsterdam, which has now assembled an archive that includes her other paintings, family photographs, letters, and related manuscripts. That primary archive of material by or on Salomon has expanded to include translations and versions of Life? or Theatre? in other media: seven films, two operas, several plays, biographies and a biographical novel, as well as numerous scholarly studies and exhibition catalogs, an official website, and various online sites. ${ }^{30}$ Each of these remediations emphasizes different moments in interpreting the visual-verbal narrative of Life? or Theatre?, creating a complex afterlife.

Recently, Dutch filmmaker Frans Weisz's 2011 biopic, Charlotte, disclosed nineteen additional painted pages of a letter forming the epilogue of Life? or Theatre? in which Salomon apparently made a shocking confession about murdering her grandfather. This new material has spurred a new generation of critical interpretation and dramatic enactments to engage with what seems to be a scandalous revelation that renders the afterlife of Salomon's work highly controversial. ${ }^{31}$ Vigorous arguments have ensued, not just about the arc of Salomon's life and the interpretation of Life? or Theatre?, but even whether her work should be invoked in Holocaust studies. Thus, Salomon may now be a variant of what Leigh 
Gilmore has termed a 'tainted witness,' one who was either unreliable, maliciously vindictive, or a liar. An alternative case, however, could be made for her as a victim of and witness to her grandfather's lifelong sexual predation on generations of women in her family. Indeed, a rhetorical reading of her long letter as autobiographical may reveal that its apparent claim to committing murder can be contextualized and understood differently, not as a scandalous act but an indeterminate narration. ${ }^{32}$ Thus, seven decades after Salomon's death, her work is open to questions about both the status of evidence and the ethics of her project, a case of how the afterlife of an autobiographical work can become more problematic when new 'evidence' is introduced.

\section{AFTERLIVES AGGREGATED BY THE CONTINUOUS NETWORKING OF DIGITAL MEDIA}

Digital media are having a profound impact on our sense of what comprises an archive and fundamentally reshaping the afterlives of autobiographical projects. With the twenty-first century explosion in digital archiving and the rise of Big Data projects, materials that were previously sequestered in less accessible official archives, institutions, and storage facilities now enter into a digital ecology of what Andrew Hoskins calls the 'continuously networked present." ${ }^{33}$ When offline documentary materials are archived online, however, their status is changed by the architecture and degree of interactivity of the platforms and coding systems used, as well as the capabilities of software and hardware. This transfer process constitutes a kind of algorithmic curation, which may be more or less - discriminating in its protocols of collection. Further, since the costs associated with digitizing archives are often significant, those who provide funding may influence what is digitized.

In addition to digitized archives, there are born-digital archives enabled and sustained by algorithmic logics that feed into repositories of Big Data. This data includes the massive amounts of information swept from social media sites, all of them generative of self-imaging, selfinscription, and self-curation. Big data includes, as well, data accumulated by governments, other security businesses, and hackers. In these online archives, researchers can track digital footprints and encounter what Kyle Cardell calls 'digital clutter, the overabundance of available documents. ${ }^{34}$ Yet, researchers depend on other researchers, as well as coders and web architects, to develop metadata and display architecture through which to find and visualize material. As Xin Huang observes, 'the metadata releases' material such as images 'from its stillness and 
gives it a new political ontology and form of agency. ${ }^{, 35}$ And yet, the archival material returned from online archives and Big Data in response to particular queries regarding pieces of evidence is only as effective as the thoughtfulness of the coders, the quality of the metadata, and the openness of the site. Whether digitized or born-digital, online archives present methodological and ethical issues for lifewriting scholars interested in the afterlives of their subjects.

Clearly, self-curators cannot control where all the bits and pieces of their online lives may be taken up, circulated, and stored in other peoples' archives, or even abandoned in the cloud. Indeed, new businesses now market self-aggregation services as a necessary part of self-curation. For example, 'Uberflip' offers to help 'centralize your existing content' by strategically rearranging and pruning data for those trying to assemble a more coherent self. Such editing, however, threatens the wealth of information that researchers seek about a subject's self-curation. ${ }^{36}$ As subjects may also include fantasies about themselves generated through gaming, Tumblr, or interactivity, future researchers may encounter the afterlives of their subjects in alternative selves presented as fantasy celebrity or avatars of heroic action. While the impact of digital media on the afterlives of life narratives are yet to be fully theorized, the kinds and extent of paratexts they enable and the multiple media they generate and store about the history and reception of autobiographical narratives suggest that afterlives may become more copious and surprising than ever.

\section{CONCLUSION}

Because the archives of life narratives are not single or static repositories of evidentiary documents but dynamic and shifting sites, their afterlives are unpredictable and unstable, changing with the assemblage technologies employed and responsive to shifts in styles and modes of selfrepresentation. Those who write, draw, or otherwise represent themselves rely on both public archives and their personal archives of storage memory and postmemory in ways that raise thorny questions about their relationship to such archives. And the afterlife of much life writing, through republication or remediation, poses questions about the entanglement of autobiographical stories in the forces and flows of circulation and reception. Thus, while the vast production of autobiographical work around the globe provides stirring models of illuminating stories in self-archives, fixing some truth of the subject remains indeterminate in them. As ever with autobiographical work, we are left with ethical and methodological questions about how to contextualize and evaluate possible afterlives. In thinking about how the interpretation of a life narrative is modified by 
situating it within the history of its afterlives, we see the following as key questions:

- How does one read for the embedded afterlife of feelings and impressions, material traces of embodiment, and gaps and synapses in a particular life writing text?

- How do the afterlives of others and their historical situation embedded in an autobiographical text enhance, shift, or contravene the reading of a narrator's own story?

- How do the afterlives imposed on a life narrative by later editorial or interpretive actors change the story, and how should that evidence be evaluated?

- When archives impose classifiable identities upon experiential histories that may reduce the felt and lived life to a template of features or activities, how do we listen for other stories, the traces of felt life in alternative afterlives?

- When a researcher discovers lives and subjectivities erased from official records, how might the available fragments and marginalia be used to sketch out a usable afterlife of a subject? What are the ethical considerations in such projects?

- In the context of online lives, is anything discoverable beyond multiple afterlives in what may be a constantly moving, algorithmic hall of mirrors?

In sum, afterlives are not an afterthought. They are, as Derrida suggests, spurs that provoke 'the question of a response' to the ongoing life of autobiographical narratives during and beyond the lifespan of their authors.

\section{BIBLIOGRAPHY}

Agger, Inger. The Blue Room: Trauma and Testimony among Refugee Women: A Psychosocial Exploration. London: Zed Books, 1994.

Antin, Mary. The Promised Land: The Autobiography of a Russian Immigrant. Boston \& New York: Houghton Mifflin, 1912.

Bechdel, Alison. Fun Home: A Family Tragicomic. Boston: Houghton Mifflin, 2006.

Bentley, Toni. 'The Obsessive Art and Great Confession of Charlotte Salomon.' 15 July 2017. https://www.newyorker.com/.../the-obsessive-art-and-great-confession-of-charlottesalomon. Date accessed: 10 August 2017.

Berlant, Lauren and Jordan Greenwald. 'Affect in the End Times: A Conversation with Lauren Berlant.' Qui Parle 20:2 (Spring/Summer 2012) 71-89.

Booth, Alison. How to Make It as a Woman: Collective Biographical History from Victoria to the Present. Chicago: University of Chicago Press, 2004.

Borden, Mary. The Forbidden Zone: A Nurse's Impressions of the First World War (1929). Hesperus Modern Voices Series. London: Hesperus Press, 2008. 
Brittain, Vera. Testament of Youth: An Autobiographical Study of the Years 1900-1925. London: Macmillan, 1934.

Brown, Malcolm. 'Foreword.' In: Mary Borden. The Forbidden Zone. A Nurse's Impressions of the First World War. Hesperus Modern Voices Series. London: Hesperus Press, 2008, vii-xi.

Cardell, Kylie. 'Modern Memory-Making: Marie Kondo, Online Journaling, and the Excavation, Curation, and Control of Personal Digital Data.' a/b: Auto/Biography Studies 32:3 (2017) 499-517.

'Child of War: The Diary of Zlata Filipović.' Newsweek. 28 February 1994, $24-27$.

Cvetkovich, Ann. An Archive of Feelings: Trauma, Sexuality, and Lesbian Pubic Cultures. Durham, NC: Duke University Press, 2003.

Derrida, Jacques. Archive Fever: A Freudian Impression. Éditions Galilée, 1995. Trans. Eric Prenowitz. Chicago: University of Chicago Press, 1996.

Douglas, Jennifer and Heather MacNeil. 'The Self: Literary and Archival Perspectives on Writers' Archives.' Archivaria: The Journal of the Association of Canadian Archivists 67 (Spring 2009) 25-39. https://archivaria.ca/index.php/archivaria/article/view/13206. Date accessed: 24 September 2020.

Frank, Anne. Anne Frank: The Diary of a Young Girl. The Definitive Edition. In: Otto H. Frank and Mirjam Pressler (eds.), Het Achterhuis [The Annex]. Amsterdam, 1947. New York: Random House, 1995.

Filipović, Zlata. Zlata's Diary: A Child's Life in Sarajevo. Zagreb: UNICEF, 1993. New York and London: Penguin, 1994.

Foenkinos, David. Charlotte. Paris: Gallimard, 2014. Trans. Sam Taylor. New York: The Overlook Press, Peter Mayer Publishers, Inc., 2016.

Genette, Gérard. Paratexts: Thresholds of Interpretation. Seuils. Paris: Éditions Seuil, 1987. Trans. Jane E. Lewin. Cambridge \& New York: Cambridge University Press, 1997.

Gilmore, Leigh. Tainted Witness: Why We Doubt What Women Say About Their Lives. New York: Columbia University Press, 2017.

Hirsch, Marianne. 'Family Pictures: Maus, Mourning and Post-Memory.' Discourse 15:2 (Winter 1992-93) 3-29.

Hirsch, Marianne. Family Frames: Photography, Narrative, and Postmemory. Cambridge, MA: Harvard UP, 1997.

Hirsch, Marianne. The Generation of Postmemory: Writing and Visual Culture After the Holocaust. New York: Columbia University Press, 2012.

Hirsch, Marianne and Leo Spitzer. postmemory.net. postmemory.net. Date accessed: 11 October 2017.

Hoskins, Andrew. 'Digital Network Memory.' In: Astrid Erll and Ann Rigney (eds.), Mediation, Remediation and the Dynamics of Cultural Memory. Berlin/Boston: DeGruyter, 2012, 91-106.

Hutchinson, Hazel. 'Introduction.' In: Mary Borden (ed.), The Forbidden Zone: A Nurse's Impressions of the First World War. Hesperus Modern Voices Series. London: Hesperus Press, 2008, xiii-xvi.

Lejeune, Philippe. 'Auto-Genesis: Genetic Studies of Autobiographical Texts.' In: Jeremy D. Popkin and Julie Rak (eds.), On Diary. Trans. Katharine Durnin. Honolulu: University of Hawai'i Press, 2009, 213-235.

Lejeune, Philippe. 'The Journal de “Jeune Fille” in Nineteenth-Century France.' In: Jeremy D. Popkin and Julie Rak (eds.), On Diary. Trans. Katharine Durnin. Honolulu: University of Hawaii Press, 2009, 129-143.

McCarthy, Mary. Memories of a Catholic Girlhood. New York: Harcourt, Brace, 1957.

Pollock, Griselda. Charlotte Salomon and the Theater of Memory. New Haven, CT: Yale University Press, 2018.

Remarque, Erich Maria. All Quiet on the Western Front. New York: Little, Brown \& Co., 1929. 
Rowlandson, Mary. A True History of the Captivity and Restoration of Mrs. Mary Rowlandson. In: William L. Andrews et al. (eds.), Journeys in New Worlds. Madison: University of Wisconsin Press, 1990, 27-65.

Salomon, Charlotte. Life? or Theatre? (Leben? oder Theater?). Trans. Leila Vennewitz (1981). New York: The Overlook Press, 2017.

Schaffer, Kay and Sidonie Smith. Human Rights and Narrated Lives: The Ethics of Recognition. New York: Palgrave Macmillan, 2004.

Scott, Joan W. 'Experience.' In: Judith Butler and Joan W. Scott (eds.), Feminists Theorize the Political. New York: Routledge, 1992.

Smith, Sidonie. 'Performativity, Autobiographical Practice, Resistance.' a/b: Auto/Biography Studies 10:1 (Spring 1995) 17-33. Reprinted In: Sidonie Smith and Julia Watson (eds.), Women, Autobiography, Theory: A Reader. Madison: University of Wisconsin Press, 1998, $108-115$.

Smith, Sidonie. 'Narratives and Rights: Zlata's Diary and the Circulation of Stories of Suffering Ethnicity.' Women's Studies Quarterly Special Issue on The Intimate and the Global. 34:1 \& 2 (Spring/Summer 2006) 133-152.

Smith, Sidonie and Julia Watson. Reading Autobiography: A Guide for Interpreting Life Narratives. $2^{\text {nd }}$ Edition. Minneapolis: University of Minnesota Press, 2010. First Edition, 2001.

Spiegelman, Art. Maus: A Survivor's Tale. I. My Father Bleeds History [1988]. II. And Here My Troubles Began [1992]. In: The Complete Maus. New York: Pantheon, 1993.

Spiegelman, Art. 'Preface.' In the Shadow of No Towers. New York: Pantheon Graphic Novels, $2004, n . p$.

Spiegelman, Art. MetaMaus: A Look Inside a Modern Classic, "Maus." Ed. Hillary Chute. New York: Pantheon, 2011.

Uberflip. https://www.uberflip.com. Date accessed: 2 November 2017.

Watson, Julia. Review essay of Charlotte Salomon. Life? or Theatre? (Leben? oder Theater?) Trans. Leila Vennewitz (1981), including the full 'Letter to Amadeus Daberlohn.' New York \& London: Overlook Duckworth, Peter Mayer, Inc., 2017. Biography 42:2 (2019) 438-451.

Weisz, Frans. Leven of Theater? (Life? or Theatre?). Film (co-written with Batya Wolff). Netherlands, 95 min., 2011.

Xin Huang. 'Excavating the Gendered Self: Digital Affordance and Photo-Auto/Biography.' a/b: Auto/Biography Studies 32:3 (2017) 519-539.

\section{ABOUT THE AUTHORS}

Sidonie Smith is the Lorna G. Goodison Distinguished University Professor Emerita of English and Women's Studies, University of Michigan, and Past President of the Modern Language Association of America (2010). Her major research interest is in autobiography studies, particularly women's life writing, life writing and human rights, and contemporary genres in textual, graphic, performance, and online media. Her publications include A Poetics of Women's Autobiography: Marginality and the Fictions of Self-Representation (1987), Subjectivity, Identity, and the Body: Women's Autobiographical Practices in the Twentieth Century (1993), and Manifesto for the Humanities: Transforming Doctoral Education in Good Enough Times (2015). With Kay Schaffer, she coauthored Human Rights and Narrated Lives (2004). With Julia Watson, she coauthored Reading Autobiography: A Guide to Interpreting Life Narratives (2010 second expanded edition) and Life Writing in the Long Run: A Smith $\mathcal{E}^{\circ}$ Watson Autobiography Studies Reader (2017). Email: sidsmith@umich.edu 
Julia Watson is Academy Professor Emerita of Comparative Studies, a core faculty member of Project Narrative, and an affiliate of Germanic Languages and Literatures at The Ohio State University. With Sidonie Smith she coauthored Reading Autobiography: A Guide for Interpreting Life Narratives (expanded edition, 2010) and co-edited five collections. Their Life Writing in the Long Run: A Smith Eु Watson Autobiography Studies Reader (2017) is accessible in open access. Watson's recent essays are on women's visual diaries, voice in Patti Smith, online publishing, reading in women's comics, and Philippe Lejeune. Email: watson.235@osu.edu

\section{NOTES}

1 Jennifer Douglas and Heather MacNeil. 'Arranging the Self: Literary and Archival Perspectives on Writers' Archives.' Archivaria 67 (Spring 2009) 25-39 (39). https:// archivaria.ca/index.php/archivaria/article/view/13206. Date accessed: 24 September 2020.

2 In the journal Archivaria: The Journal of the Association of Canadian Archivists, Jennifer Douglas and Heather MacNeil argue that 'the capacity of a writer's archive to reveal character and intention, inevitably, is constrained by the writer's own efforts to conceal and edit the self, and by the imposition of intentions of persons other than the writer on the archive' (25). While Douglas and MacNeil raise a pertinent question on whether 'it is possible for archivists to represent a writer's records without imposing their own intentions on that representation,' their concern with the specialist's archival tenets and creating 'a usable working order' for researchers (29) are different aims than ours, although we concur that '[t]he archivists' reconstruction and representation of a writer's archive inevitably introduce new layers of narrative into the writer's archive' (noting that our work on life writing is a main source of evidence for this assertion) (31). As Douglas and MacNeil sum up, drawing on Chapter 3 of Reading Autobiography (2001), ' $[t]$ he author of a diary or letter does not merely reveal herself in the text, but instead creates a version of herself that exists only in the text' (34). In this essay, however, our interest is in the afterlives of life writing texts as uses of the writer's various personal effects and the organization and editions of their works.

3 See Sidonie Smith. 'Narratives and Rights: Zlata's Diary and the Circulation of Stories of Suffering Ethnicity.' Women's Studies Quarterly Special Issue on The Intimate and the Global 34:1 \& 2 (Spring/Summer 2006) 133-152.

4 'Child of War: The Diary of Zlata Filipović,' Newsweek, 28 February 1994 (27).

5 Ann Cvetkovich. An Archive of Feelings: Trauma, Sexuality, and Lesbian Pubic Cultures. Durham, NC: Duke University Press, 2003 (268).

6 Cvetkovich. An Archive of Feelings, 269.

7 Cvetkovich notes that Derrida "explores the mechanisms by which memory leaves its material traces or "impressions," and the arbitrary relation between the material object and the psychic life it marks' (An Archive of Feelings, 268).

8 Mary Borden. The Forbidden Zone: A Nurse's Impressions of the First World War. Hesperus Modern Voices Series. London: Hesperus Press, 2008.

9 Erich Maria Remarque. All Quiet on the Western Front. New York: Little, Brown \& Co., 1929; and Vera Brittain. Testament of Youth: An Autobiographical Study of the Years 1900-1925. London: Macmillan, 1934.

10 Hazel Hutchinson. 'Introduction' to The Forbidden Zone, xiv. 
11 Hutchinson. 'Introduction,' xiv.

12 Borden. The Forbidden Zone, 11.

13 Borden. The Forbidden Zone, 12.

14 Borden. The Forbidden Zone, 13.

15 Borden. The Forbidden Zone, 13.

16 Malcolm Brown. 'Forward,' Mary Borden, The Forbidden Zone, xi.

17 Mary Antin. The Promised Land: The Autobiography of a Russian Immigrant. Boston \& New York: Houghton Mifflin, 1912. The Promised Land first appeared in serial form in the Atlantic Monthly in 1911 and 1912.

18 Antin. The Promised Land, 90-91.

19 Mary McCarthy. Memories of a Catholic Girlhood. New York: Harcourt, Brace, 1957 (34).

20 McCarthy. Memories, 50.

21 McCarthy. Memories, 164-165.

22 Alison Bechdel. Fun Home: A Family Tragicomic. Boston: Houghton Mifflin, 2006 (134).

23 Bechdel. Fun Home, 186.

24 Art Spiegelman. 'Preface.' In the Shadow of No Towers. New York: Pantheon Graphic Novels, 2004 (n.p.).

25 Spiegelman assembled archives of this evidence to support his representation of Holocaust events in Maus, first in a Hyperstax CD, then in the volume MetaMaus.

26 See Marianne Hirsch's argument in 'Family Pictures: Maus, Mourning and Post-Memory.' Discourse 15:2 (Winter 1992-93) 3-29. See also its further development in Family Frames: Photography, Narrative, and Postmemory. Cambridge MA: Harvard UP, 1997; her essay 'The Generation of Postmemory.' Poetics Today 29:1 (2008) 103-128; and The Generation of Postmemory: Writing and Visual Culture After the Holocaust. New York: Columbia University Press, 2012.

27 Marianne Hirsch and Leo Spitzer. postmemory.net. postmemory.net. Date accessed: 11 October 2017.

28 See Alison Booth. How to Make It as a Woman: Collective Biographical History from Victoria to the Present. Chicago: University of Chicago Press, 2004. Booth explores how prosopography, in England, from the mid- nineteenth-century to the twentieth century, arose as publishers assembled women's stories into biographical volumes on groups of women sharing some kind of history, profession, or status. In: Reading Autobiography, Smith and Watson define prosopography as 'a practice of making a collective study of the characteristics shared by a group whose members' biographies often cannot be referenced, in order to discover relationships and patterns among their lives at a particular historical moment' (278).

29 See Gérard Genette. Paratexts: Thresholds of Interpretation (Seuils. Paris: Editions du Seuil, 1987. Trans. Jane E. Lewin. Cambridge and New York: Cambridge University Press, 1997. Genette terms all that surrounds a story its paratextual material. There are peritextual materials inside the book, which are added in the publishing process and may include its cover, inside covers, introduction, chapter titles and breaks, epigraphs (for example, in Maus, one from Hitler), dedication, photographs and so forth. These may change significantly with different editions of the book. Epitextual materials that 'surround' a narrative are attached to a book after publication. They may include advertising, interviews, reviews, and the like. Genette argues that, while paratextual materials may appear to be 'neutral,' in fact they create a threshold that affects how the book is received and interpreted by various reading communities. See also Sidonie Smith and Julia Watson, Reading Autobiography, 99-100.

30 In 2011 Dutch filmmaker Frans Weisz released a documentary entitled Leven of Theater? (Life? or Theatre?), Film (co-written with Batya Wolff) (Netherlands, 95 min., 2011). The film was linked to the 1981 biographical dramatization Charlotte, which he co-wrote and 
filmed. (It is one of seven films on her and her family's lives and work.) Also in 2014 French composer Marc-André Dalvabie's opera 'Charlotte Salomon' premiered at the Salzburg Festival and was staged in Bielefeld, Germany, in January 2017. Prolific French biographer David Foenkinos's 2015 Charlotte, a novel in poetic verse, was translated into several European languages (Charlotte. Paris: Gallimard, 2014. Trans. Sam Taylor. New York: The Overlook Press, Peter Mayer Publishers, Inc., 2016). The 2016 exhibition at Musée Masséna in Nice of Salomon's work was staged to mass acclaim. Art historian Griselda Pollock's critical study is illuminating on this point. See Charlotte Salomon and the Theater of Memory. New Haven, CT: Yale University Press, 2018.

31 See Weisz's film and The New Yorker online essay 'The Obsessive Art and Great Confession of Charlotte Salomon.' 15 July 2017 by Toni Bentley for a discussion of the letter-writer persona Charlotte's seeming revelation that she murdered her grandfather. https:// www.newyorker.com/.../the-obsessive-art-and-great-confession-of-charlotte-salomon.

Art historian Griselda Pollock's critical study (Yale University Press, 2018) argues that the letter is part of the fictional world constructed for Salomon's persona.

32 Julia Watson's review essay of the new edition of Life? or Theatre? provides a full discussion of details of the film and the allegation, and argues that the films' lack of attention to rhetorical specifics of the letter, as well as Weisz' willful distortion of its disclosures, lead him to a problematic conclusion. See Review essay of Charlotte Salomon. Life? or Theatre? (Leben? oder Theater?) Trans. Leila Vennewitz (1981), including the full 'Letter to Amadeus Daberlohn.' New York \& London: Overlook Duckworth, Peter Mayer, Inc., 2017. Biography 42:2 (2019).

33 Andrew Hoskins. 'Digital Network Memory.' In: Astrid Erll and Ann Rigney (eds.), Mediation, Remediation and the Dynamics of Cultural Memory. Berlin/Boston: DeGruyter, 2012 (101).

34 For an extended discussion of tracks and digital 'clutter,' see Kylie Cardell. 'Modern Memory-Making: Marie Kondo, Online Journaling, and the Excavation, Curation, and Control of Personal Digital Data.' a/b: Auto/Biography Studies 32:3 (2017) 506. Cardell adopts the phrase from Andrew Hoskins.

35 Xin Huang. 'Excavating the Gendered Self: Digital Affordance and Photo-Auto/ Biography.' a/b: Auto/Biography Studies 32:3 (2017) 527.

36 'Uberflip' describes itself as a strategic 'cloud-based Content Experience Platform.' https://www.uberflip.com. 